\title{
Optimization of producing oil and meal from canola seeds using microwave - pulsed electric field pretreatment
}

\author{
Nazanin Maryam Mohseni ${ }^{1}$, Habib Ollah Mirzaei ${ }^{2, *}$ and Masoumeh Moghimi ${ }^{3}$ \\ ${ }^{1}$ Department of Food Science and Technology, Sari Branch, Islamic Azad University, Sari, Iran \\ 2 Department of Food Materials and Process Design Engineering, University of Agricultural Sciences and Natural Resources, Gorgan, \\ Iran \\ ${ }^{3}$ Department of Chemistry, Gonbad Kavoos Branch, Islamic Azad University, Gonbad Kavoos, Iran
}

Received 2 July 2019 - Accepted 5 November 2019

\begin{abstract}
In this study, optimization of the extraction of canola seeds oil was investigated using microwave-pulsed electric field seeds pretreatment (MW-PEF) with different MW times (0 to $200 \mathrm{~s})$ and PEF intensities ( 0 to $5 \mathrm{kV} / \mathrm{cm}$ ). The seeds oil was then extracted using screw press with different speeds (11 to $57 \mathrm{rpm}$ ). Oil extraction efficiency, refractive index, peroxide and phenolic compounds of oil and meal protein were measured. Tocopherols content of the best sample was also measured. The results showed that the peroxide and phenolic compounds increased at higher time, intensity and speed. An increase in the MW time and PEF intensity at first led to an increase in the oil extraction efficiency and meal protein but then both parameters decreased. The efficiency of oil extraction and protein decreased at higher speeds. The refractive index of all samples was 1.475. Gamma tocopherol was predominate one in canola oil and applying the pretreatment led to an increase in the number of total tocopherols. Treating at $1.28 \mathrm{kV} / \mathrm{cm}$ for $140.5 \mathrm{~s}$ and $28.71 \mathrm{rpm}$ was chosen as the optimum condition with high desirability (0.744).
\end{abstract}

Keywords: pretreatment / canola / microwave / pulsed electric field / oil

\begin{abstract}
Résumé - Optimisation de la production d'huile et de tourteaux à partir de graines de canola prétraitées par microondes et champ électrique pulsé. Dans cette étude, l'optimisation de l'extraction d'huile de graines de canola a été étudiée en utilisant un prétraitement des graines par micro-ondes et champs électriques pulsés (M0-CEP), avec différentes durées sous MO (0 à $200 \mathrm{~s}$ ) et différentes intensités de CEP $(0$ à $5 \mathrm{kV} / \mathrm{cm})$. L'huile de graines a ensuite été extraite à l'aide d'une presse à vis à différentes vitesses (11 à $57 \mathrm{tr} / \mathrm{min}$ ). L'efficacité de l'extraction de l'huile, l'indice de réfraction, les peroxydes et composés phénoliques de l'huile ainsi que la protéine du tourteau ont été mesurés. La teneur en tocophérols du meilleur échantillon a également été mesurée. Les résultats ont montré que les peroxydes et composés phénoliques augmentaient avec le temps, l'intensité et la vitesse. Une augmentation du temps de MO et de l'intensité des CEP a tout d'abord entraîné une augmentation de l'efficacité d'extraction de l'huile et de la protéine du tourteau, mais a ensuite diminué les deux paramètres. L'efficacité de l'extraction de l'huile et la protéine ont diminué aux vitesses les plus élevées. L'indice de réfraction de tous les échantillons était de 1,475. Le gamma-tocophérol était prédominant dans l'huile de canola et l'application du prétraitement entraînait une augmentation de la concentration en tocophérols totaux. Le traitement à $1,28 \mathrm{kV} / \mathrm{cm}$ pour une durée de $140,5 \mathrm{~s}$ et à $28,71 \mathrm{tr} / \mathrm{min}$ a été choisi comme condition optimale avec une désirabilité élevée $(0,744)$.
\end{abstract}

Mots clés : prétraitement / canola / micro-ondes / champ électrique pulsé / huile

\section{Introduction}

The oilseeds are the second important food reserves of the world after cereals and meanwhile, canola is considered as one

*Correspondence: Mirzaei. habib@gmail.com of the main oilseeds all over the world (Ashraf and McNeilly, 2004; Azimi et al., 2012). Canola is the modified rapeseed that is the result of genetic manipulations in Brassica napus and Brassica Rapa species. Its extracted oil contained 2\% Erucic acid and $30 \mathrm{mg}$ Glucosinolate per one gram of dried meal. In comparison to the other oil seeds, canola should specific 
characteristics such as having higher oil content; hence, this seed is more economic value among the oilseeds and having numerous agricultural benefits. Canola is known as one of the most important oilseeds therefore many researchers studied its properties (Przybylski and Mag, 2011). Varieties of canola can belong to one species of Matthiola family including Rapeseed (Brassica napus L.), oil Turnip (B. rapa (campestris) L.) and Indian mustard (B. juncea L.) (Barthet, 2016). Because of having high amounts of unsaturated fatty acids and low amounts of saturated fatty acids ( $71 \%$ or less), the canola oil is considered as an important and healthy source of edible oil (Gul and Ahmad, 2004; Gerzhova et al., 2016). After soybean and oil palm, canola is the third source for oil production (Rathke et al., 2006). The method of nurturing the rapeseed is one of the effective factors on the seeds function, oil percentage and the quality of its seed. The canola oil is the only edible oil that contains sulphureted fatty acids. The unsaturated fatty acids are formed the main part of fatty acid compounds in canola oil (Ohara et al., 2009). In comparison to the other oil seeds, rapeseed showed more phenolic compounds (Nowak et al., 1992). Sinapic acid and its derivatives, most notable Sinapine, are the most significant of them. Most of the phenolic compounds remain in the meal during the seed pressing, but most abundantly vinylsyringol is founded in crude rapeseed oil (Koski et al., 2003). The lower phenols recovery of the heat-treated seed is related to the incomplete extraction using $70 \%$ ethanol due to complexation with heat-denatured protein (Naczk et al., 1992). It was mentioned canolol as the substance isolating from crude canola oil. Canolol shows high antioxidant capacity and antimutagenic properties (Koski et al., 2003; Kuwahara et al., 2004; Vuorela et al., 2004, 2005; Wakamatsu et al., 2005). According to Kuwahara et al. (2004), its anti-mutagenic potency is higher than that a-tocopherol and flavonoids. In rapeseed, sinapic acid derivatives are the predominant phenolics. Canolol can be produced by decarboxylation of sinapic acid during the press process or roasting of the seeds (Koski et al., 2003; Kuwahara et al., 2004). Thus, the food value of the rapeseed and rapeseed oil may be enhanced by elevating the canolol content through press processing or the roasting of rapeseed before pressing.

Applying microwave (MW) leads to a reduction in the oil extraction process time as well as the energy consumption, for this reason, several studies and researches are performed in the case of using these waves in oil extraction. The kinetics of rapeseed oil and tocopherols extraction was studied during MW treatment. Results indicated that using these waves in each time and temperature increased the process efficiency and Fick's modified diffusion model was the best one to describe the extracting oil process (Sánchez et al., 2017). MW pretreatment was applied in extracting oil from Moringa seeds with supercritical solvent in laboratory scale (Da Porto et al., 2016). The results of this research indicated that the extraction efficiency increased by applying MW and also the use of supercritical solvent caused producing better and higher quality oil in comparison to the oil extracted using Soxhlet.

The pulsed electric field (PEF) process, as a non-thermal method, is widely used to optimize the energy consumption and preserve the qualitative properties of the food products. During recent years, this method is used in industrial scales in biotechnology, pharmacy, making stimulus lasers, cleaning of
Table 1. Experimental levels of each independent variable: MW time (X1), PEF intensity (X2) and rotational speed of screw press (X3).

\begin{tabular}{lrll}
\hline Number & X1 & X2 & X3 \\
\hline 1 & 0 & 0 & 34 \\
2 & 200 & 0 & 34 \\
3 & 0 & 5 & 34 \\
4 & 200 & 5 & 34 \\
5 & 0 & 2.5 & 11 \\
6 & 200 & 2.5 & 11 \\
7 & 0 & 2.5 & 57 \\
8 & 200 & 2.5 & 57 \\
9 & 100 & 0 & 11 \\
10 & 100 & 5 & 11 \\
11 & 100 & 0 & 57 \\
12 & 100 & 5 & 57 \\
13 & 100 & 2.5 & 34 \\
14 & 100 & 2.5 & 34 \\
15 & 100 & 2.5 & 34 \\
16 & 100 & 2.5 & 34 \\
17 & 100 & 2.5 & 34 \\
\hline
\end{tabular}

metals and polymer materials, producing and processing the foodstuffs such as fruits extract, milk and liquid eggs. This process consists of applying some pulses in short times (about microsecond times) at the strong electric field intensities on the foodstuff placed between two electrodes at room temperature. PEF with high intensity cause the electrical decomposition of cells and increases their permeability (Pourzaki and Mirzaee, 2009; Schroeder et al., 2009). Some researchers studied the effective parameters of the PEF at the time of extracting oil from sunflower seeds. They studied the effect of different parameters such as the PEF intensity, frequency, pulse width, treatment time and also amount of the solvent on the efficiency of oil extraction from sunflower seeds. The results indicated that when the seeds were treated with a PEF $(7 \mathrm{kV} / \mathrm{cm}, 1.5 \mathrm{~Hz}$, $30 \mu \mathrm{s}$ [pulse width] for 90 seconds) the efficiency of oil extraction was increased about 9.1\%. Eventually, they stated that it's possible to use this process in extracting oil from sunflower seeds in higher scales (Shorstkii et al., 2017). Zeng et al. (2010) and Bakhshabadi et al. (2018) were some other researchers who had used PEF for oil extraction (Zeng et al., 2010; Bakhshabadi et al., 2018). Researchers showed that application of combined pretreatment of hydrothermal-MW leads to increase in the efficiency of oil extraction (Cortese et al., 2019). In the previous studies, only one pre-treatment was applied individually to enhance the oil extraction while in the current study, two different sequential pre-treatment (MW and PEF) were used to increase the efficiency of canola oil extraction.

\section{Materials and methods}

\subsection{Materials and equipment}

The canola seeds (contain $41.3 \%$ oil) were provided from the local market of Fars Province (Iran) to perform this 
research. Then, the external materials such as weed seeds, sand, and stones were separated and removed from it by hand and the seeds were transferred to Food Industry Laboratory of the Islamic Azad University of Gonbad-e-Kavoos and Modern technologies laboratory of Food Industry Research Institute to perform some experiments. Equipment that was used in this research consists of laboratory sieves, desiccator, laboratory oven (Member, made I Germany), digital balance (Gec Avery, made in England), refractometer (Abbe, Cruise, made in Germany), microwave device (LG, made in South Korea), pulsed electric field device that was made in Food Industry Research Institute of Iran, high performance liquid Chromatography (Knauer, made in Germany), Scanning electron microscope (SEM) (Oxford, England) and laboratory screw press (Kern Kraft, Made in Germany).

\subsection{Applying compound pretreatment on the seeds and extracting oil}

The canola seeds were affected and treated by MW pretreatment with power of 540 Watt and different process times $(0,100$ and $200 \mathrm{~s})$. After MW treatment, the samples were transferred to the water chamber and let it cooled down up to room temperature $\left(25^{\circ} \mathrm{C}\right)$. Then, the seeds were treated by PEF at three intensities $(0,2.5$ and $5 \mathrm{kV} / \mathrm{cm})$ with fixed pulse numbers of 30 . PEF process was carried out by a unipolar batch PEF generator system, producing logarithmic pulses with $0.5 \mathrm{~ms}$ duration. The capacity of process chamber was $4 \mathrm{~L}$. The camber was filed with seeds $(0.5 \mathrm{~kg})$ and water $(1 \mathrm{~kg})$ as the conductive liquid. The chamber and two parallel electrodes were made of the transparent carbonate (Plexiglas) and stainless steel, respectively. The maximum voltage of instrument was $7 \mathrm{kV}$ and its capacitance was $8 \mu \mathrm{F}$ (Guderjan et al., 2005; Uquiche et al., 2008; Bakhshabadi et al., 2017). The moisture content of the seeds homogenously control and reduced to $6 \%$ by drying at $50{ }^{\circ} \mathrm{C}$; then, the oil of seeds was extracted using screw press with different speeds (11 to $57 \mathrm{rpm}$ ) and various experiments were performed on oils and proteins.

\subsection{Calculating the efficiency of oil extraction (oil extraction efficiency)}

The amount of extraction efficiency was obtained using equation (1) and with a digital balance based on the introduced method by Bakhshabadi et al. (2017). It should be mentioned that to control the effect of moisture content on the efficiency of oil extraction, the seeds had uniform moisture content.

$$
\text { Extraction yield }(\%)=\frac{\text { Extractedoil }(\mathrm{g})}{\text { Seeds }^{\prime} \text { weight }} \times 100
$$

\subsection{Measure the refractive index}

After sedimentation, the oil drop was obtained from the surface to measure the oil refractive index according to the AOCS Cc 7-25 method (1994) using refractometer device at $25^{\circ} \mathrm{C}$ (AOCS and Firestone, 1994).

\subsection{Determine the peroxide index}

The peroxide amount of oils was measured according to AOCS Dd 8-53 method (1994).

\subsection{Determine the amount of total phenolic compounds}

The amount of total phenolic compounds was determined with the colorimetry method using Folin Ciocalteu's phenol reagent (Bail et al., 2008).

\subsection{Measure the number of tocopherols in the optimized and control sample}

Determine and measure the number of total tocopherols was performed according to the AOCS Ce 8-89 method (1994) with a high-performance liquid chromatography device (HPLC). For this purpose the 5-60 column (HICHROSORB) with dimensions of $250 * 4.5 \mathrm{~mm}$ and particle size of $5 \mu$, with fluorescence detector was used. The mobile phase has selected a combination of Acetonitrile with distilled water at a 95 to 5 ratio and was used. The flow rate of mobile phase was $0.6 \mathrm{~mL} /$ min. the number of tocopherols in samples was determined on the basis of the remaining time of tocopherols and also the chromatogram resulted from oil samples. The oil of control sample, without applying any pre-treatments, was extracted using screw press (34 rpm).

\subsection{Measure the protein}

The amount of nitrogen in the seeds was measured using the fully-automated Kjedahl device and according to the (Association of Official Analytical Chemists) AOAC 03-990 (2008). After titration, the amount of nitrogen was calculated and the protein amount of the meals was measured using the conversion factor of 6.25 (AOAC, 2008).

\subsection{Scanning electron microscopy analysis (SEM)}

The scanning electron microscope was used to study the structure of samples (control and treated one). At first, after it was assured that samples are dried, they were glued on the aluminum base using silica glue and then, the bases were coated in a gold coating/sputtering device. At last, imaging from samples was performed in magnification of 1000 .

\subsection{Statistical analysis}

The response surface methodology using the Box-Behnken design was used to evaluate the fixed parameters of study, MW time $\left(\mathrm{X}_{1}\right)$, PEF intensity $\left(\mathrm{X}_{2}\right)$, rotational speed of screw press $\left(\mathrm{X}_{3}\right)$ on the amount of oil extraction efficiency, refractive index, peroxide and phenolic compounds and protein amount of meals the variable parameters (Tab. 1). Using this design and method, all coefficients of the second-order regression model and interaction of factors are measurable and estimable. The most important case in this research is to study the interaction of factors and finding the best condition of the oil 
Table 2. Model selection for dependent (response) variables.

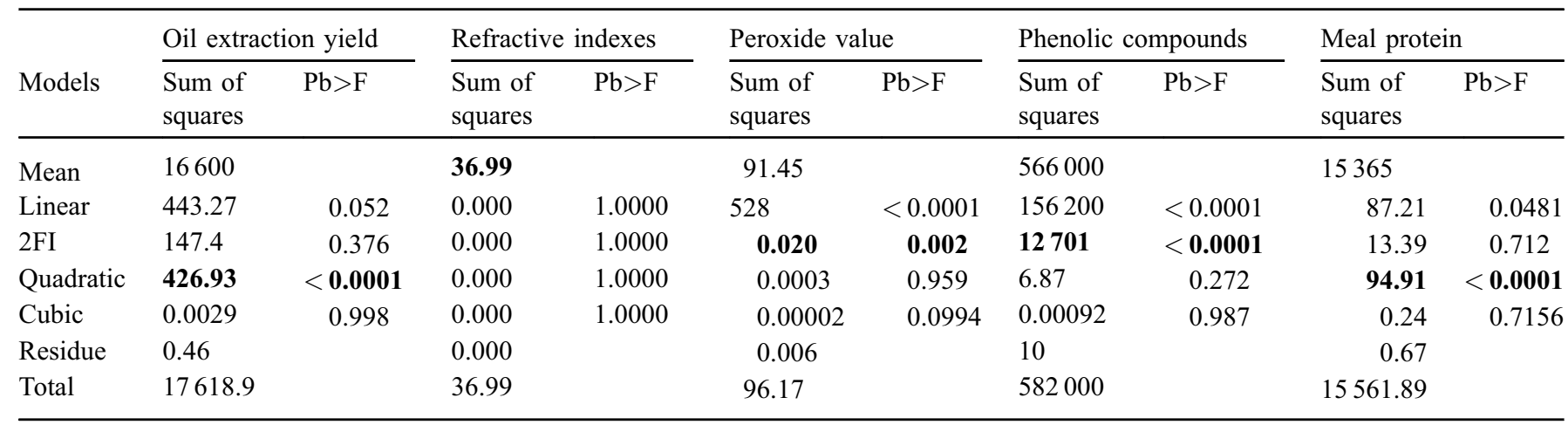

Note: The suggested models are shown on bold highlighting.

extraction process and producing a protein-rich meal from canola seeds, therefore, the response surface statistical design was selected. A quadratic polynomial equation was fitted for each independent variable to evaluate the behavior of response surfaces. Finally, the ASA software was used to compare the samples obtained from optimization pretreatment with control sample for the number of tocopherols and Duncan's multiple range tests were used to compare the data means.

\section{Results and discussions}

\subsection{The influence of studied parameters on the efficiency of oil extraction}

As shown in Table 2, the quadratic model was the best model to interpret oil extraction efficiency. Table 3 indicated that all of the studied parameters had a significant effect on oil extraction efficiency $(P<0.001)$. As represented in Figure 1, the oil extraction efficiency increased at first and then reduced by an increase in the MW time and PEF intensity. Also, the figures obtained from scanning electron microscope (SEM) (Fig. 2) confirmed that using this pretreatment lead to texture destruction and create more pores and outlets resulting in better oil extraction from seeds. Also, the results of this part indicated that the oil extraction efficiency decreased with an increase in the rotational speed of screw press because of a decrease in the pressure on seeds. The MW causes to evaporate water from plant structure and pressure increase in the internal environment and this case can lead to material decomposition, membrane disintegration, increase in the oil extraction efficiency using press and oil passing from the cell membrane (Aguilera and Stanley, 1999). Researchers reported that the efficiency of extraction process can be increased by an increase in the MW time (Oomah et al., 1998; Azadmard-Damirchi et al., 2010; Sánchez et al., 2017). Also, the results of this part indicated that the efficiency of the extraction process decreased with an increase in the rotational speed of press because reducing in the pressure on the samples (Deli et al., 2011). An increase in the oil extraction efficiency with increase in the PEF intensity can be related to an increase in the membrane degradability index (Sarkis et al., 2015). The oil extraction efficiency was decreased with an excessive increase in the MW time and PEF intensity, probably because of more degradation in the internal structure of seeds and closure of oil outlet. It was reported that heat treatment with micronutrients results in more efficient extraction of the seed compounds by reducing the moisture content, enzymatic inactivation, or changes in lipid structure in soybean pellets (List et al., 1990). Pradhan et al. (2011) investigated the effect of baking process and moisture content on some oil properties of peeled Jatropha seeds. The results showed that the oil extraction efficiency reduced because of using the high temperatures and also producing an elastic state by increase in the moisture content of the kernels. Baking at $110^{\circ} \mathrm{C}$ for $10 \mathrm{~min}$ was chosen as optimum condition. The increase in temperature, due to the reduction in viscosity of the oil as well as the cell wall degradation, speeds up the extraction rate, increase the oil extraction and reduce the oil remaining in the meal. In high protein content seed, the use of high temperatures reduces the lubrication efficiency due to the excessive alteration in protein structure (Pradhan et al., 2011).

The following model (Eq. (2)) represents the linear relationship between the extraction efficiency and independent variable:

$$
\begin{aligned}
y & =+38.40+2.42 \mathrm{X}_{1}-3.78 \mathrm{X}_{2}-5.94 \mathrm{X}_{3}-1.87 \mathrm{X}_{1} \mathrm{X}_{2} \\
& +5.09 \mathrm{X}_{1} \mathrm{X}_{3}-2.73 \mathrm{X}_{2} \mathrm{X}_{3}-5.52 \mathrm{X}_{1}^{2}-7.65 \mathrm{X}_{2}^{2} \\
& -2.02 \mathrm{X}_{3}^{2} .
\end{aligned}
$$

\subsection{The influence of operational parameters on the refractive index}

All of the test variables (MW time, PEF intensity and the rotational speed of screw press) showed no effect on the oil refractive index. In this research, the refractive index of oil resulted from canola seeds was obtained equal to 1.475 (Fig. 3). The model that is related to the fitted data refractive index for samples is presented as equation (3):

$$
\mathrm{y}=+1.48 \text {. }
$$

The results of this research conformed to the researchers who studied the physicochemical characteristics of orange seed oil that is extracted with different methods and stated that new methods of extraction in comparison to common methods can't change some of the physical characteristics of oil such as refractive index (Gorji et al., 2016). On the other hand, results 
N.M. Mohseni et al:: OCL 2020, 27, 2

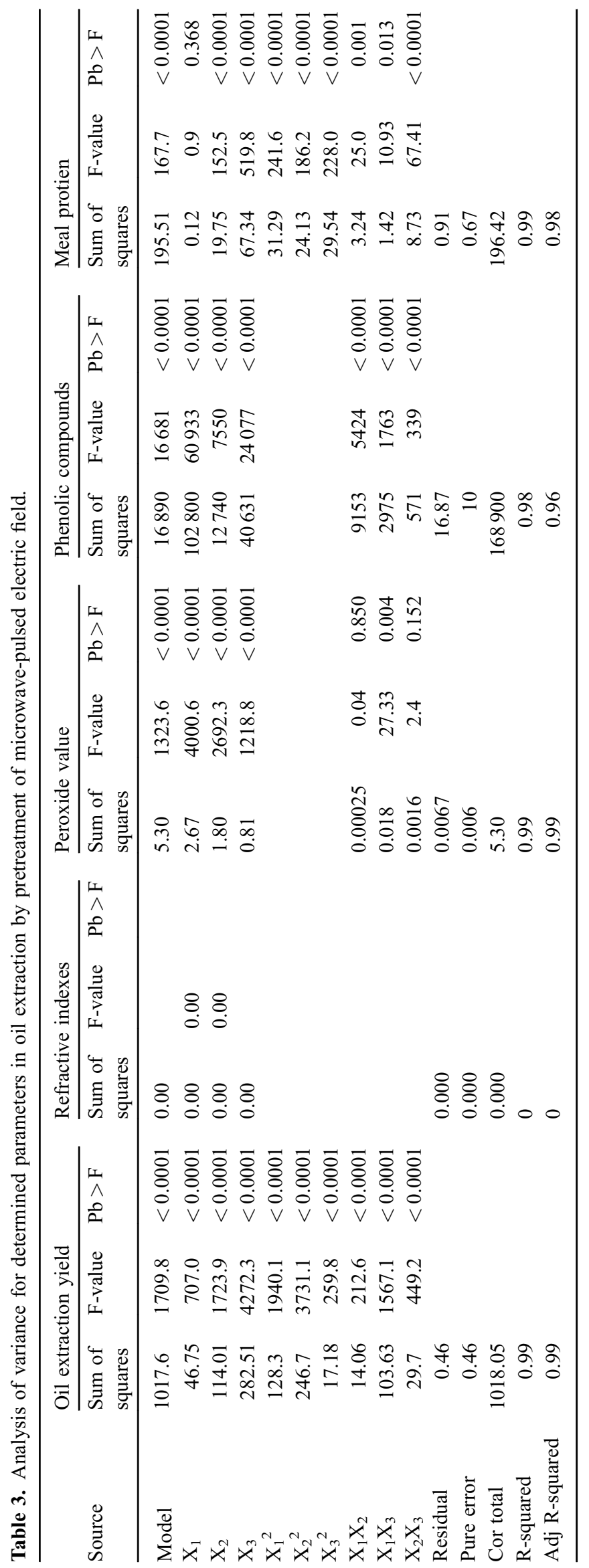

Page 5 of 12 


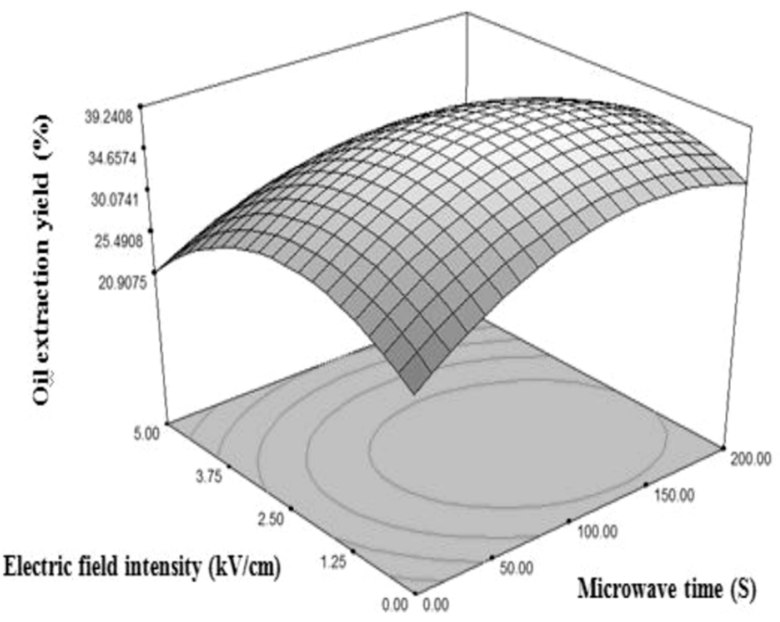

(a)

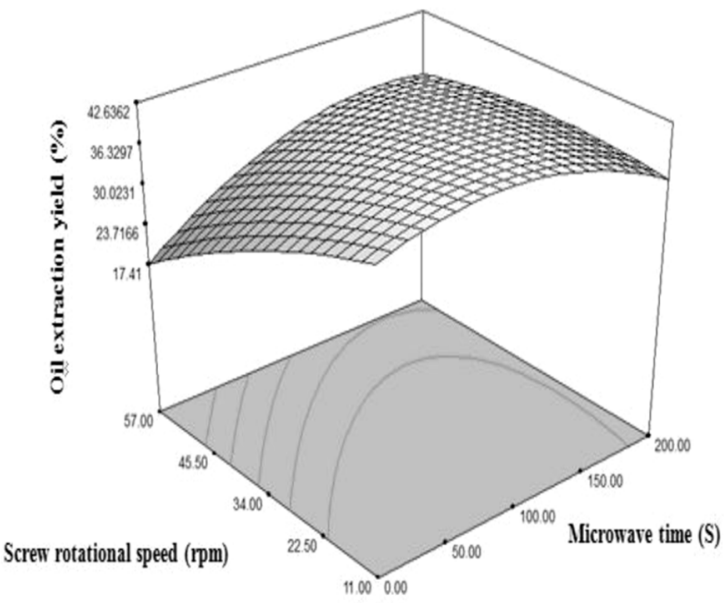

(b)

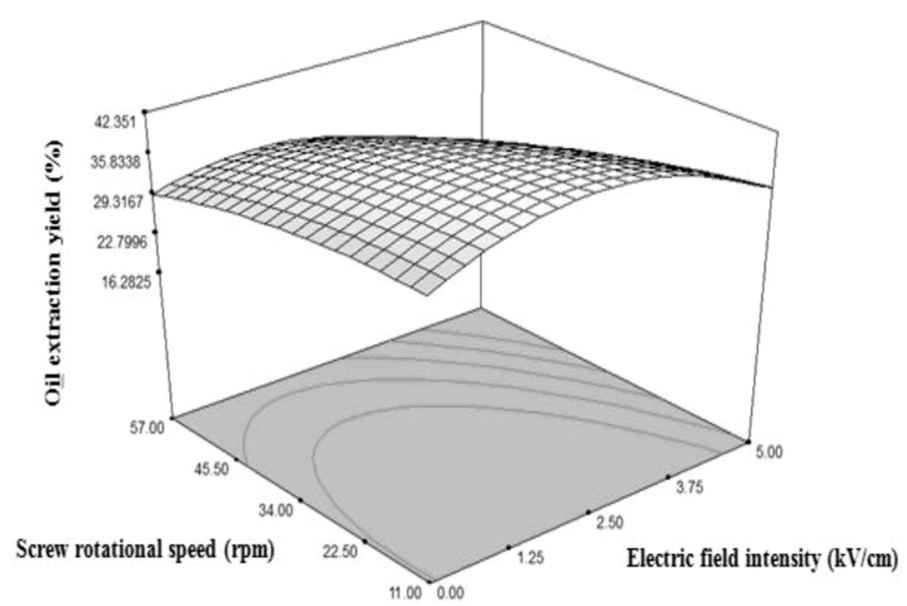

(c)

Fig. 1. Three-dimensional diagrams: the influence of (a) microwave time and electric field intensity, (b) microwave time and the rotational speed of screw press and (c) intensity of electric field and rotational speed of screw press on the oils extraction yield.

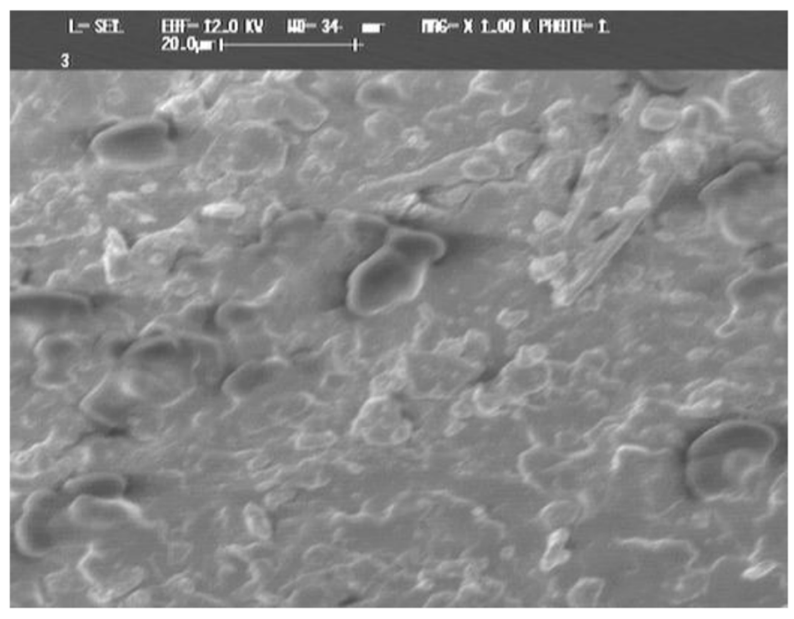

(a)

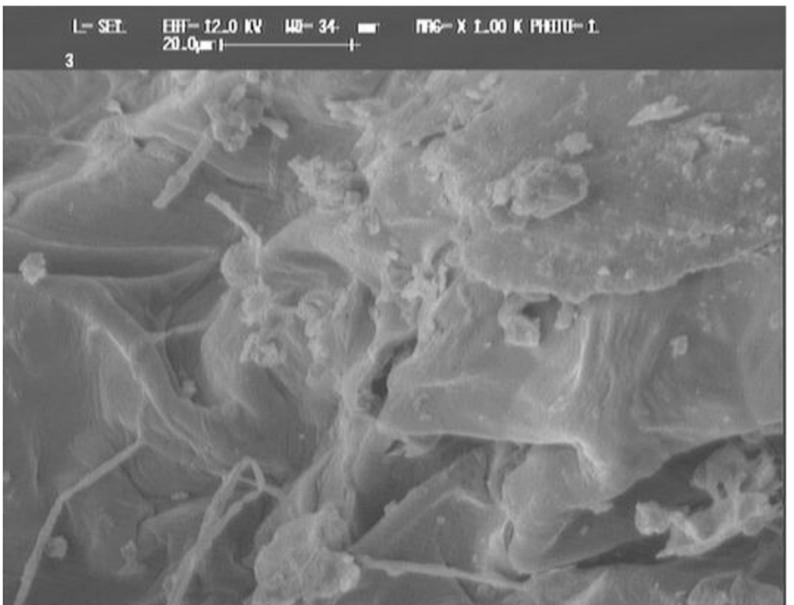

(b)

Fig. 2. SEM diagrams from (a) control sample (without treatment) and (b) treatment sample. 


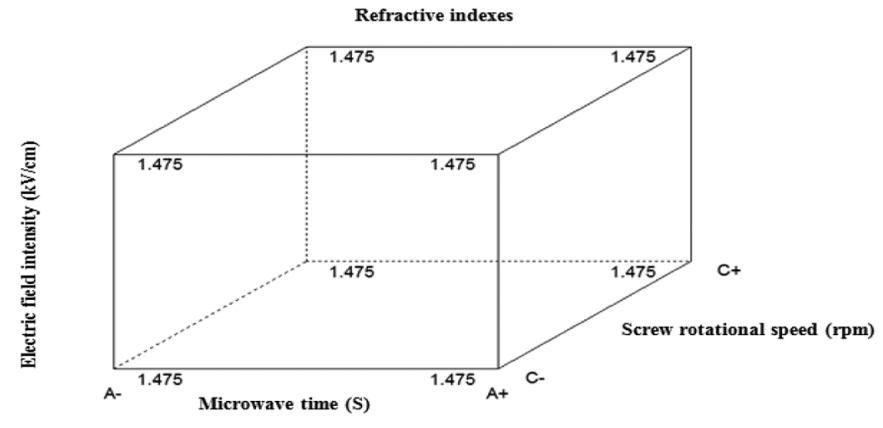

Fig. 3. Cube diagram of changes in the amount of oils refractive index under the influence of microwave time, electric field intensity, and the rotational speed of screw press.

of Uquiche et al. (2008) and Tale Masouleh et al. (2015) confirmed these results, too (Uquiche et al., 2008; Tale Masouleh et al., 2015). On the other hand, lack of variation and change in the refractive index of oils obtained from this process can be attributed to the similarity of fatty acid profiles in the non-treated and treated samples.

\subsection{The influence of understudied fixed variables on the amount of peroxide in oils}

According to Table 2, the best-selected model for fitting the data obtained from samples peroxide was a 2 FI model that on the basis of that the fitted model for these data was equation (4):

$$
\begin{aligned}
y & =+2.32+0.58 \mathrm{X}_{1}+0.47 \mathrm{X}_{2}+0.32 \mathrm{X}_{3} \\
& +0.00025 \mathrm{X}_{1} \mathrm{X}_{2}+0.068 \mathrm{X}_{1} \mathrm{X}_{3}+0.020 \mathrm{X}_{2} \mathrm{X} .
\end{aligned}
$$

From the above-mentioned model and also number $\mathrm{F}$, it can be found that the linear parameter of MW time and after that the linear parameter of PEF intensity has the most influence on the peroxide amount of oils. The variance analysis (Tab. 3) indicated that the linear parameters and also mutual parameters of MW time with the rotational speed of the screw press had a significant influence in this model. The relationship between studied parameters (Fig. 4) clearly indicated that the peroxide amount increased with an increase in the MW time, PEF intensity and the rotational speed of screw press. The reason for the increase in the peroxide amount can be attributed to more oxidation of fatty acids that will become more with temperature increase (Guderjan et al., 2007). The results of this part conformed to results and findings of other researchers who had stated that oils peroxide index will increase with rising in the temperature (Valentov et al., 2000; Hassanein et al., 2003; Zeng et al., 2010). These researchers stated that conditions and types of applied operations on the oilseeds had a significant impact on the oil peroxide amount. It was also mentioned that oxidation of compounds such as phospholipids and photooxidation phenomena also plays an important role in the highness of peroxide amount in oil extraction.

\subsection{The influence of operational parameters on the phenolic compounds}

Studying the changes of the total phenolic compounds in canola oil indicated that MW time had a positive effect on the content of total phenolic compounds; it means that with an increase in the MW time, the amount of these compounds significantly increased. Also, an increase in the PEF and the rotational speed of press had a similar trend on this characteristic (Fig. 5). The model that is related to the fitted data for total phenolic compounds is as equation (5):

$$
\begin{aligned}
y & =+577.02+113.37 \mathrm{X}_{1}+39.91 \mathrm{X}_{2}+71.27 \mathrm{X}_{3} \\
& -47.84 \mathrm{X}_{1} \mathrm{X}_{2}+27.28 \mathrm{X}_{1} \mathrm{X}_{3}+11.96 \mathrm{X}_{2} \mathrm{X}_{3} .
\end{aligned}
$$

The natural compounds (phenols) can increase the shelf life of food materials through preventing the growth of pathogenic microorganisms that corrupt the food and also through protecting food materials from damage and losses resulted from oxidative stress (Padmashree et al., 2007). Phenolic compounds are the large group of secondary herbal metabolites which their antioxidant ability results from the existence of hydroxyl groups in their structure (Muanda et al., 2011). The principles of heating using MW energy are related to the direct influences of these waves on the molecules with mechanisms of dipolar rotation and ionic conduction. The polar molecules such as phenolic compounds and ionic solutions absorb too much MW energy because of having a dipole moment that results to increase in temperature and quick reaction completion and this case will lead to enter more of these compounds into the oil (Proestos and Komaitis, 2008). With the increase in the PEF intensity and the rotational speed of press because of more releasing and entering of these compounds into the oil the amount of these compounds was increased. The results of this part are conformed to the results reported by other researchers (Boussetta et al., 2014; Jiao et al., 2014). The main phenolic compounds in crude postexpelled rapeseed oil were vinylsyringol (a decarboxylation product of sinapic acid) followed by sinapine and sinapic acid. The content of phenolics decreased during processing which is in agreement with the found results during studying the call (vinylsyringol) in crude rapeseed oil (Koski et al., 2003; Kuwahara et al., 2004). The pre-expelled rapeseed oil contained only a small amount of phenolics indicating that higher temperature $\left(<100^{\circ} \mathrm{C}\right)$ and pressure are necessary for release of the phenolics into rapeseed oil.

\subsection{The influence of studied parameters on the protein amount of meal}

The optimized use of a protein that is required for the body is dependent on the digestibility and pattern of essential amino acids in food sources that are provided for the body. Hence, determining the amount of protein and evaluating the used food materials, are necessary for food programming and feeding to provide humans biological needs (Taghizadeh et al., 2007). On the other hand, pricing the meals in oil extraction plants is on the base of the amount of their protein and humidity (Rostami et al., 2014). Table 3 indicated that all of the studied parameters except MW time had significant influence of the protein amount of meal $(P<0.001)$ and on the other hand, regarding the Table 2, it was characterized that the best model for interpreting and determine the amount of protein in the meal was the quadratic model. As it is clear in Figure 6, similar to the oil extraction efficiency, with an increase in the 


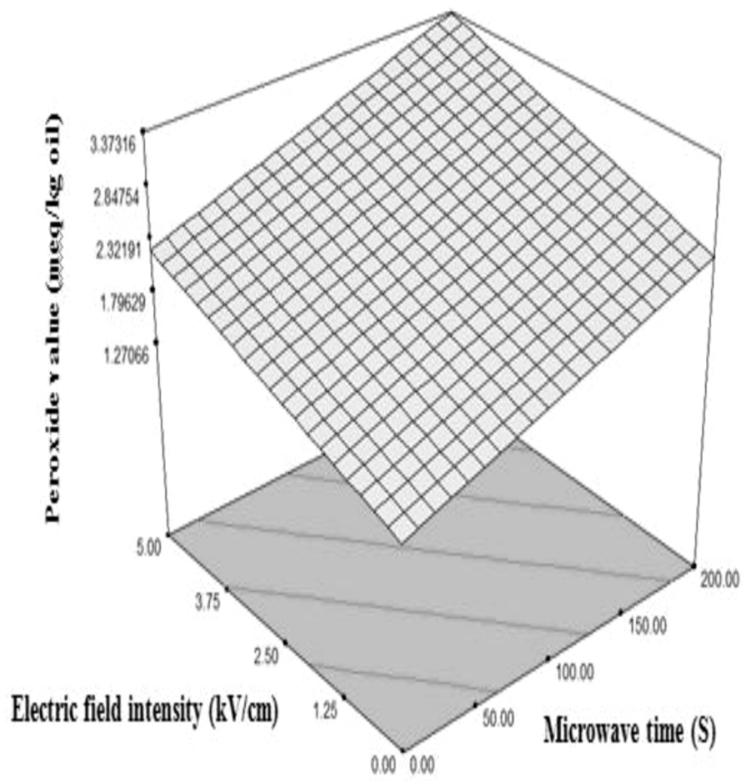

(a)

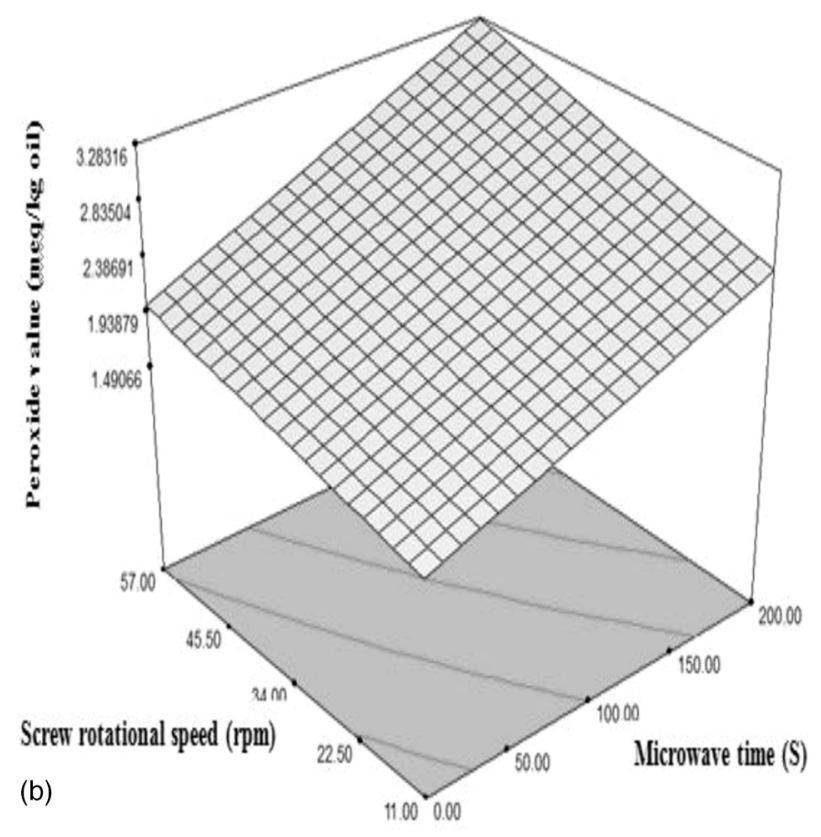

(c)

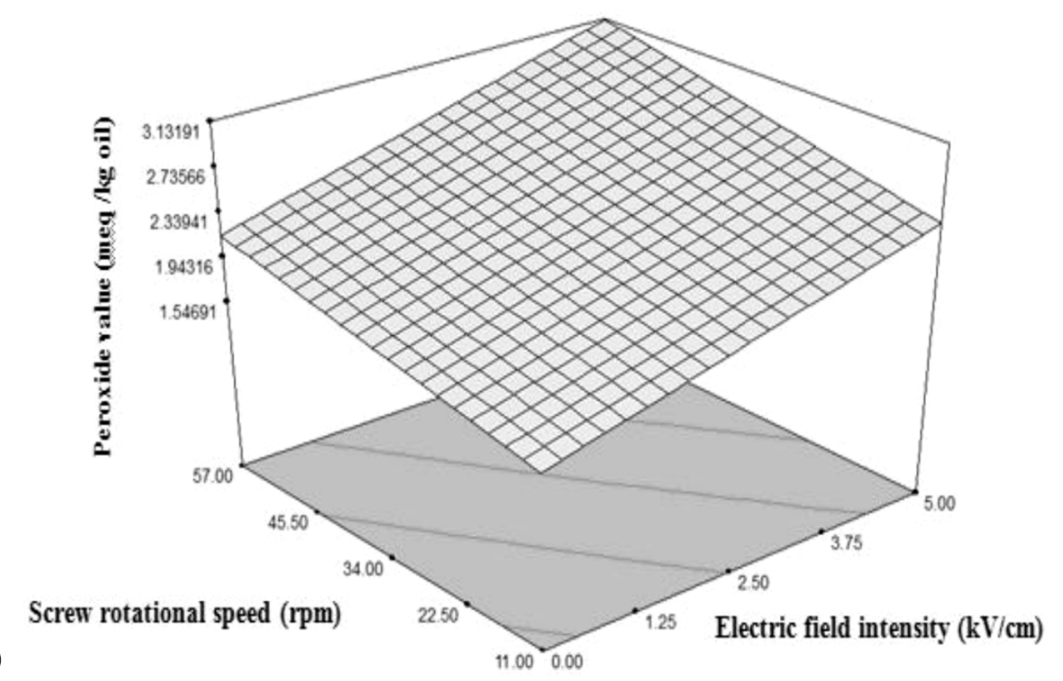

Fig. 4. Three-dimensional diagrams: the influence of (a) microwave time and electric field intensity, (b) microwave time and rotational speed of screw press and (c) intensity of electric field and rotational speed of screw press on the oils peroxide amount.

MW time and PEF intensity, the amount of protein increased at first and decreased then. Also, the results of this part indicated that with an increase in the rotational speed of the screw press the amount of protein in the meal decreased. Applying MW caused an increase in the amount of dissolved protein in the meal. The results of this part confirmed the results of studies performed by others (Choi et al., 2006). The amount of protein in the meal decreased with an increase in the rotational speed of the press, because of protein denaturation and also remaining more oil in the meal. Also, it was indicated that using a PEF caused an increase in the amount of extracted protein (Sarkis et al., 2015). The results of this part were conformed to the results of Bakhshabadi et al. (2018). The final model that is presented in the following for the protein amount of meal and also the F-number indicated more influence of linear variable of rotational speed in screw press on this factor (Eq. (6)):

$$
\begin{aligned}
y & =+32.72+0.12 \mathrm{X}_{1}-1.57 \mathrm{X}_{2}-2.90 \mathrm{X}_{3}-0.90 \mathrm{X}_{1} \mathrm{X}_{2} \\
& +0.59 \mathrm{X}_{1} \mathrm{X}_{3}-1.48 \mathrm{X}_{2} \mathrm{X}_{3}-2.73 \mathrm{X}_{1}^{2}-2.39 \mathrm{X}_{2}^{2} \\
& -2.65 \mathrm{X}_{3}^{2} .
\end{aligned}
$$

\subsection{Optimization of oil extraction from canola}

To find the best condition of extracting oil from canola seeds using MW-PEF pretreatment, regarding the MW time 


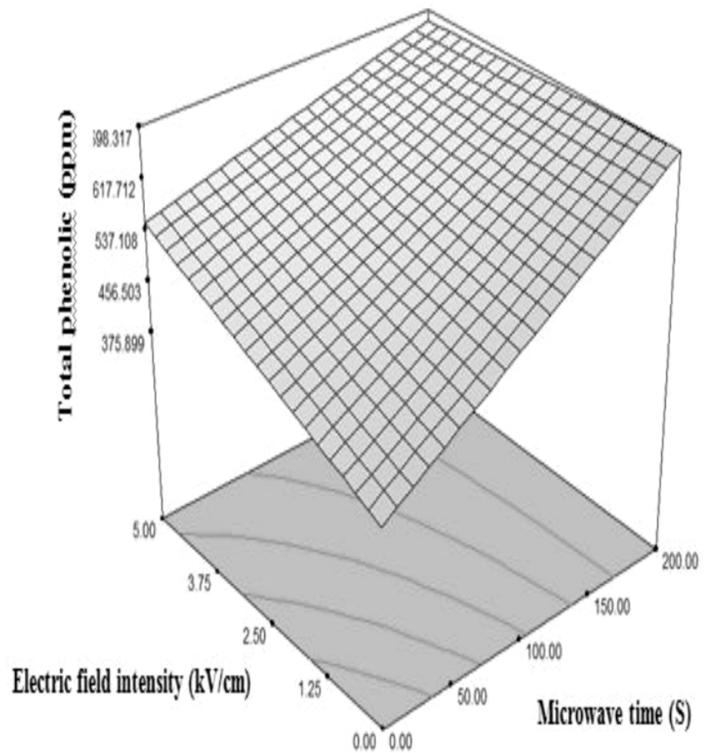

(a)

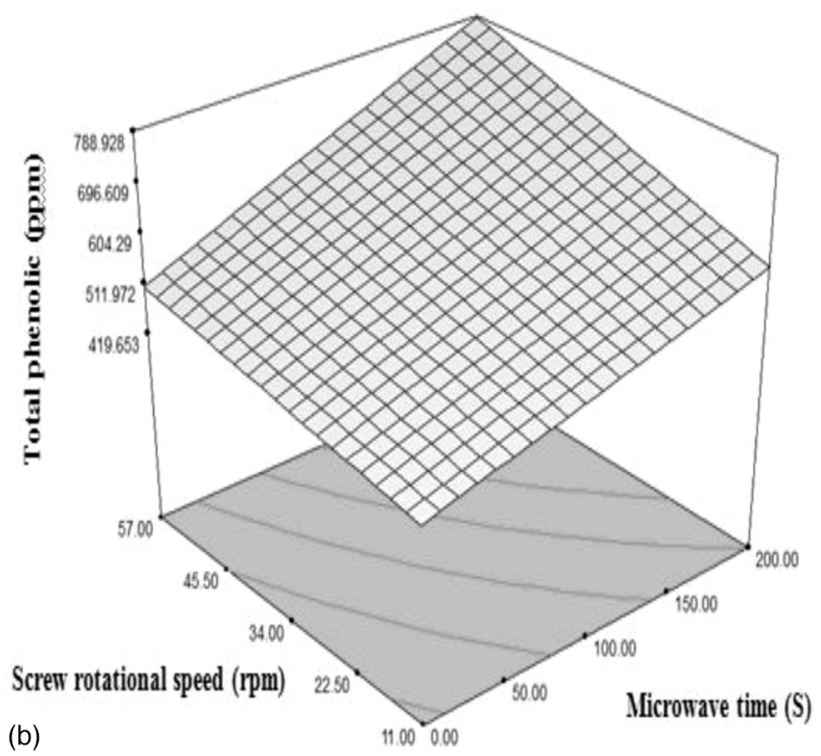

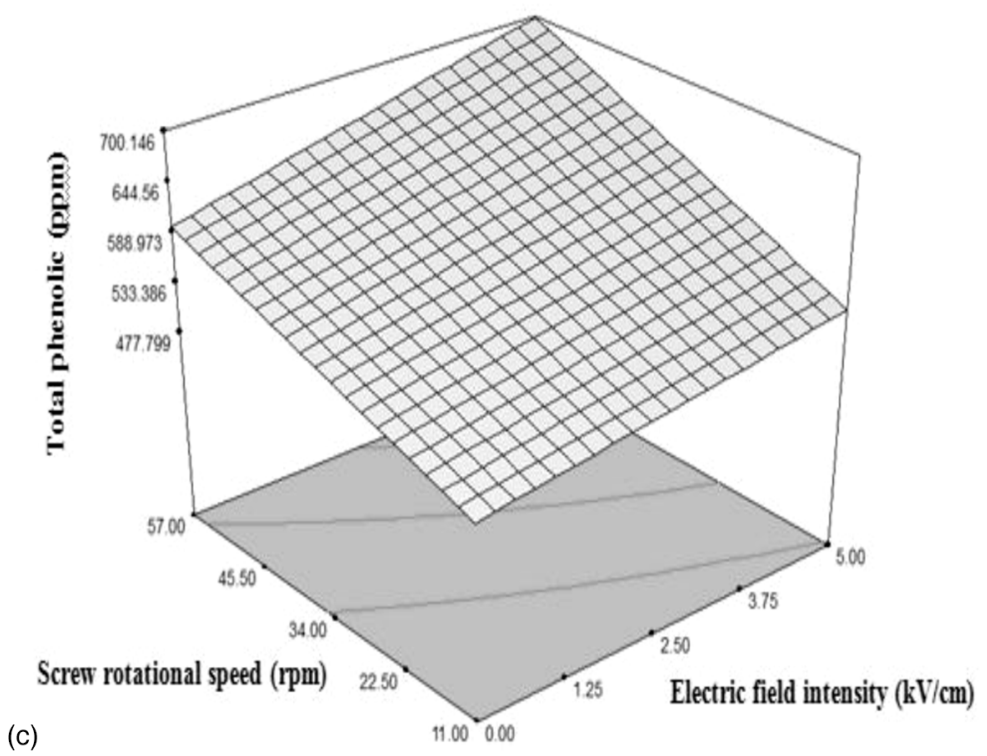

Fig. 5. Three-dimensional diagrams: the influence of (a) microwave time and electric field intensity, (b) microwave time and the rotational speed of screw press and (c) electric field intensity and the rotational speed of screw press on the oils phenolic compounds.

that was set between 0 to 200 seconds, and PEF intensity that was set in the range of 0 to $5 \mathrm{kV} / \mathrm{cm}$ and rotational speed of screw press that was set between 11 to $57 \mathrm{rpm}$, the oil extraction process in the above mentioned conditions was optimized to reach the maximum amount of extraction efficiency, protein in meal and total phenolic compounds and minimizing the amount of peroxide. The results indicated that to reach the mentioned aims, its necessary to set the MW time to 140.51 seconds, the PEF intensity to $1.28 \mathrm{kV} / \mathrm{cm}$ and the rotational speed of screw press to $28.71 \mathrm{rpm}$ to reach the desirability of 0.744 in the above-mentioned conditions.

\subsection{The influence of MW-PEF on the number of total tocopherols in oil}

The mean comparison of data obtained from tocopherols amount indicated that gama tocopherol was the most tocopherol in the oil of both optimized and control samples that was after the alpha-tocopherol (Tab. 4). As it is clear, applying the pretreatment led to increasing in the number of total tocopherols of canola oil and this effect is especially seen in the number of delta tocopherols because this tocopherol is not seen and found in the oil that was extracted without using 


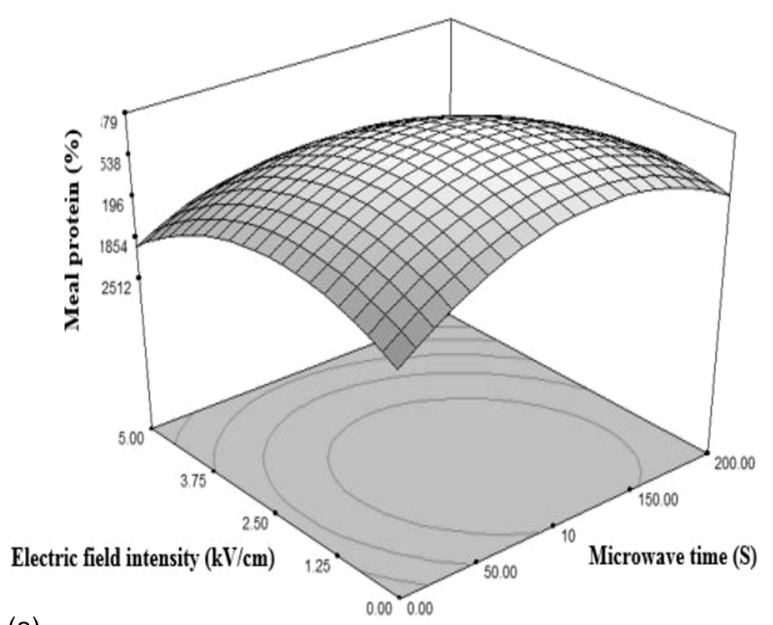

(a)

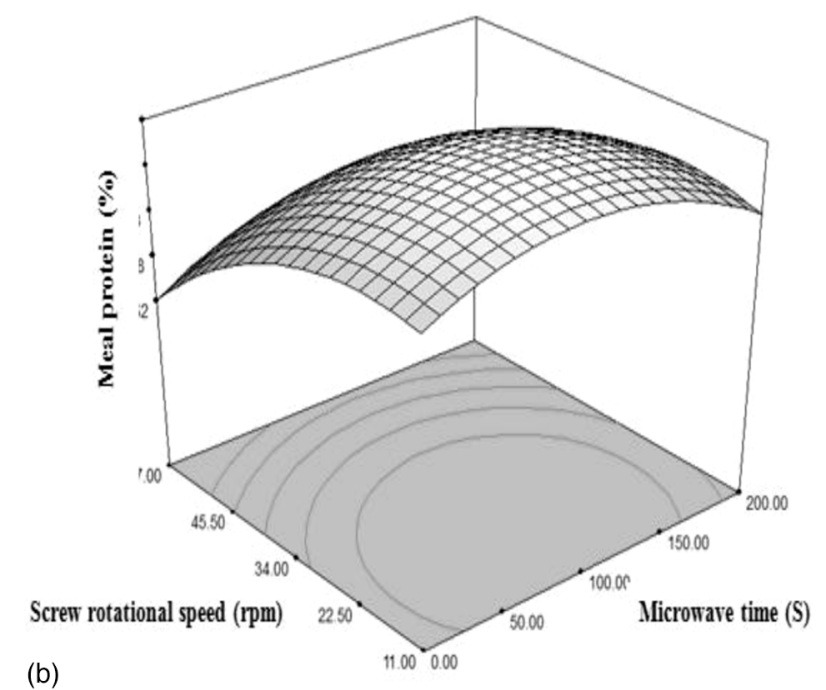

(b)

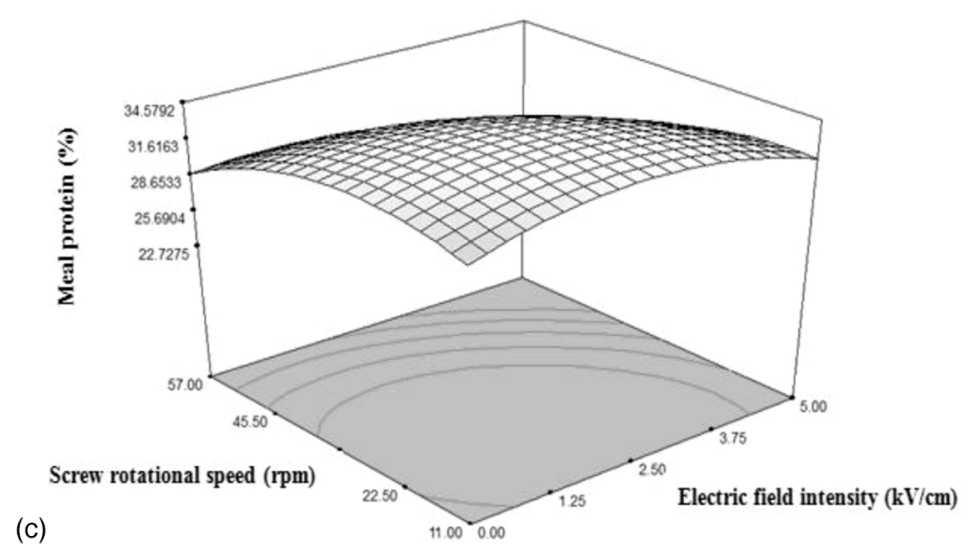

Fig. 6. Three-dimensional diagrams: the influence of (a) microwave time and electric field intensity, (b) microwave time and the rotational speed of screw press and (c) electric field intensity and the rotational speed of screw press on the protein amount of meal.

Table 4. Tocopherols of canola seeds oil achieved by different pretreatment.

\begin{tabular}{lcc}
\hline Tocopherols type & \multicolumn{1}{c}{ Standard } & Optimized sample \\
\hline Alpha tocopherols $(p p m)$ & $367.3 \pm 1.94^{\mathrm{aB}}$ & $351.02 \pm 25.80^{\mathrm{aB}}$ \\
Delta tocopherols $(\mathrm{ppm})$ & $0.00^{\mathrm{bC}} \pm 0.00^{\mathrm{bC}}$ & $30.07 \pm 0.24^{\mathrm{aC}}$ \\
Gama tocopherols $(\mathrm{ppm})$ & $602.05 \pm 4.80^{\mathrm{aA}}$ & $644.52 \pm 1.02^{\mathrm{aA}}$ \\
Total tocopherols $(\mathrm{ppm})$ & $969.78 \pm 6.74$ & $1025.61 \pm 27.06$ \\
\hline
\end{tabular}

The similar capital and small letter in each column and row respectively demonstrating the non-significant difference in the confidence level of 0.05 .

pretreatment. Applying the combined pretreatment during the oil extraction causes more tocopherols to enter the oil because of a decrease in the reaction between antioxidant compounds with polysaccharides, proteins, and peptides of seed (Bakhshabadi et al., 2018). The results of this part confirmed with the findings in other studies (Wiktor et al., 2015). It was reported an increase in the amount of vitamin $\mathrm{E}$ in the grape oil using MW pretreatment, and the most amount of tocopherol was obtained during $9 \mathrm{~min}$ of treatment (Oomah et al., 1998). Studying and considering the studies of other researchers indicated that the amount of alpha-tocopherol, gama tocopherol, and delta tocopherols about 300, 400, and $15 \mathrm{ppm}$, respectively (Ahmed et al., 2005; Guderjan et al., 2007). This effect is also confirmed by other studies reporting no loss in tocopherols was observed during the thermal processing of seeds and explained this as being due to the protective activity of canolol (Wakamatsu et al., 2005; Spielmeyer et al., 2009). It was suggested that formation of canolol during roasting can protect the tocopherols against degradation at higher temperatures (Thiyam-Holländer et al., 2012). Roasting of different rapeseed varieties (typical high linolenic rapeseed variety "Brandy" and "PR46W20"; high oleic acid rapeseed HO PN1414) reflected that the content of canolol, as well as $\gamma-T$ 
and $\mathrm{PC}-8$, are highest during roasting at $180^{\circ} \mathrm{C}$. This showed a synergistic relationship between the content of canolol and the tocopherols (Siger et al., 2015; Gracka et al., 2016).

\section{Conclusion}

The results of this research indicated that with an increase in the MW time, PEF intensity and rotational speed of screw press the amount of peroxide and phenolic compounds of samples increased, while the efficiency of oil extraction and protein of meal increased at first and decreased then. The amount of refractive index of oils was not influenced by the pretreatment conditions. The report obtained from highperformance liquid chromatography device indicated that gama tocopherol was the dominant tocopherol among the canola oil tocopherols and applying pretreatment led to an increase in the number of total tocopherols of oil. At last, it can be stated that applying the MW-PEF can be presented and determined as an appropriate pretreatment in the oil extraction industry.

\section{References}

Aguilera JM, Stanley DW. 1999. Microstructural principles of food processing and engineering. Springer Science \& Business Media.

Ahmed MK, Daun JK, Przybylski R. 2005. FT-IR based methodology for quantitation of total tocopherols, tocotrienols and plastochromanol-8 in vegetable oils. J Food Comp Anal 18: 359-364.

AOAC. 2008. Association of Official Analytical Chemists. Vol. II. Arlington, VA: Association of Official Analytical Chemists.

AOCS, Firestone D. 1994. Official methods and recommended practices of the American Oil Chemists' Society. AOCS press.

Ashraf M, McNeilly T. 2004. Salinity tolerance in Brassica oilseeds. Crit Rev Plant Sci 23: 157-174.

Azadmard-Damirchi S, Habibi-Nodeh F, Hesari J, Nemati M, Achachlouei BF. 2010. Effect of pretreatment with microwaves on oxidative stability and nutraceuticals content of oil from rapeseed. Food Chem 121: 1211-1215.

Azimi GM, Dehdari A, Faraji H, Movahhedi DM, Ali NM. 2012. Effects of salinity on some quantitative and qualitative characteristics of spring rapeseed cultivars.

Bail S, Stuebiger G, Krist S, Unterweger H, Buchbauer G. 2008. Characterisation of various grape seed oils by volatile compounds, triacylglycerol composition, total phenols and antioxidant capacity. Food Chem 108: 1122-1132.

Bakhshabadi H, Mirzaei H, Ghodsvali A, Jafari SM, Ziaiifar AM, Farzaneh V. 2017. The effect of microwave pretreatment on some physico-chemical properties and bioactivity of Black cumin seeds' oil. Indus Crops Prod 97: 1-9.

Bakhshabadi H, Mirzaei H, Ghodsvali A, Jafari SM, Ziaiifar AM. 2018. The influence of pulsed electric fields and microwave pretreatments on some selected physicochemical properties of oil extracted from black cumin seed. Food Sci Nutr 6: 111-118.

Barthet V. 2016. Canola: overview. Reference module in food science. 5 .

Boussetta N, Soichi E, Lanoiselle J-L, Vorobiev E. 2014. Valorization of oilseed residues: extraction of polyphenols from flaxseed hulls by pulsed electric fields. Indus Crops Prod 52: 347-353.

Choi I, Choi SJ, Chun JK, Moon TW. 2006. Extraction yield of soluble protein and microstructure of soybean affected by microwave heating. J Food Process Preserv 30: 407-419.
Cortese C, Portela G, Sánchez R, Fernández M. 2019. Improving the canolol amount and the yield of expressed canola oil applying combined pre-treatments. Int Food Res J 26.

Da Porto C, Decorti D, Natolino A. 2016. Microwave pretreatment of Moringa oleifera seed: effect on oil obtained by pilot-scale supercritical carbon dioxide extraction and Soxhlet apparatus. $J$ Supercritic Fluids 107: 38-43.

Deli S, Farah Masturah M, Tajul Aris Y, Wan Nadiah W. 2011. The effects of physical parameters of the screw press oil expeller on oil yield from Nigella sativa L seeds. Int Food Res $J 18$.

Gerzhova A, Mondor M, Benali M, Aider M. 2016. Study of total dry matter and protein extraction from canola meal as affected by the $\mathrm{pH}$, salt addition and use of zeta-potential/turbidimetry analysis to optimize the extraction conditions. Food Chem 201: 243-252.

Gorji N, Golmakani MT, Mesbahi GR, Niakosari M, Eskandari MH, Mazidi S. 2016. Studying the physicochemical properties of orange seed oil that is extracted with different methods. Iran $J$ Food Sci Technol 54: 121-133.

Gracka A, Jeleń HH, Majcher M, Siger A, Kaczmarek A. 2016. Flavoromics approach in monitoring changes in volatile compounds of virgin rapeseed oil caused by seed roasting. $J$ Chromatogr A 1428: 292-304.

Guderjan M, Töpfl S, Angersbach A, Knorr D. 2005. Impact of pulsed electric field treatment on the recovery and quality of plant oils. $J$ Food Eng 67: 281-287.

Guderjan M, Elez-Martínez P, Knorr D. 2007. Application of pulsed electric fields at oil yield and content of functional food ingredients at the production of rapeseed oil. Innov Food Sci Emerg Technol 8: 55-62.

Gul H, Ahmad R. 2004. Effect of different irrigation intervals on growth of canola (Brassica napus L.) under different salinity levels. Pak J Bot 36: 359-372.

Hassanein MM, El-Shami SM, El-Mallah MH. 2003. Changes occurring in vegetable oils composition due to microwave heating. Grasas y Aceites 54: 343-349.

Jiao J, Li Z-G, Gai Q-Y, et al. 2014. Microwave-assisted aqueous enzymatic extraction of oil from pumpkin seeds and evaluation of its physicochemical properties, fatty acid compositions and antioxidant activities. Food Chem 147: 17-24.

Koski A, Pekkarinen S, Hopia A, Wähälä K, Heinonen M. 2003. Processing of rapeseed oil: effects on sinapic acid derivative content and oxidative stability. Eur Food Res Technol 217: $110-114$.

Kuwahara H, Kanazawa A, Wakamatu D, et al. 2004. Antioxidative and antimutagenic activities of 4-vinyl-2, 6-dimethoxyphenol (canolol) isolated from canola oil. J Agric Food Chem 52: 43804387.

List G, Mounts T, Lanser A, Holloway R. 1990. Effect of moisture, microwave heating, and live steam treatment on phospholipase D activity in soybeans and soy flakes. $\mathrm{J}$ Am Oil Chem Soc 67: 867-871.

Muanda FN, Soulimani R, Diop B, Dicko A. 2011. Study on chemical composition and biological activities of essential oil and extracts from Stevia rebaudiana Bertoni leaves. LWT-Food Sci Technol 44: 1865-1872.

Naczk M, Shahidi F, Sullivan A. 1992. Recovery of rapeseed tannins by various solvent systems. Food Chem 45: 51-54.

Nowak H, Kujawa K, Zadernowski R, Roczniak B, KozŁowska H. 1992. Antioxidative and bactericidal properties of phenolic compounds in rapeseeds. Lipid/Fett 94: 149-152.

Ohara N, Naito Y, Kasama K, et al. 2009. Similar changes in clinical and pathological parameters in Wistar Kyoto rats after a 13-week 
dietary intake of canola oil or a fatty acid composition-based interesterified canola oil mimic. Food Chem Toxicol 47: 157-162.

Oomah BD, Liang J, Godfrey D, Mazza G. 1998. Microwave heating of grapeseed: effect on oil quality. J Agric Food Chem 46: 4017-4021.

Padmashree A, Roopa N, Semwal A, Sharma G, Agathian G, Bawa AS. 2007. Star-anise (Illicium verum) and black caraway (Carum nigrum) as natural antioxidants. Food Chem 104: 59-66.

Pourzaki A, Mirzaee H. 2009. New high voltage pulse generators. Recent Patents Electr Electron Eng (Formerly Recent Patents on Electrical Engineering) 2: 65-76.

Pradhan RC, Mishra S, Naik SN, Bhatnagar N, Vijay VK. 2011. Oil expression from Jatropha seeds using a screw press expeller. Biosyst Eng 109: 158-166.

Proestos C, Komaitis M. 2008. Application of microwave-assisted extraction to the fast extraction of plant phenolic compounds. LWT-Food Sci Technol 41: 652-659.

Przybylski R, Mag T. 2011. Canola/rapeseed oil. Vegetable oils in food technology: composition, properties and uses. 98 .

Rathke G-W, Behrens T, Diepenbrock W. 2006. Integrated nitrogen management strategies to improve seed yield, oil content and nitrogen efficiency of winter oilseed rape (Brassica napus L.): a review. Agric Ecosyst Environ 117: 80-108.

Rostami M, Farzaneh V, Boujmehrani A, Mohammadi M, Bakhshabadi H. 2014. Optimizing the extraction process of sesame seed's oil using response surface method on the industrial scale. Indus Crops Prod 58: 160-165.

Sánchez R, Mateo C, Fernández M, Nolasco S. 2017. Bidimensional modeling applied to oil extraction kinetics of microwavepretreated canola seeds. J Food Eng 192: 28-35.

Sarkis JR, Boussetta N, Blouet C, Tessaro IC, Marczak LDF, Vorobiev E. 2015. Effect of pulsed electric fields and high voltage electrical discharges on polyphenol and protein extraction from sesame cake. Innov Food Sci Emerg Technol 29: 170-177.

Schroeder S, Buckow R, Knoerzer K. 2009. Numerical simulation of pulsed electric field (PEF) processing for chamber design and optimization, International Conference on CFD in the Minerads and Process Industries CSIRO, 17th, Australia.

Shorstkii I, Mirshekarloo MS, Koshevoi E. 2017. Application of pulsed electric field for oil extraction from sunflower seeds: electrical parameter effects on oil yield. J Food Proc Eng 40: e12281.

Siger A, Kaczmarek A, Rudzińska M. 2015. Antioxidant activity and phytochemical content of cold-pressed rapeseed oil obtained from roasted seeds. Eur J Lipid Sci Technol 117: 1225-1237.

Spielmeyer A, Wagner A, Jahreis G. 2009. Influence of thermal treatment of rapeseed on the canolol content. Food Chem 112: 944-948.

Taghizadeh M, Asemi Z, Shaker Hoseini R, Aminpour A, Valaiee N. 2007. Biological evaluation and comparison of soy protein quality. Sci J Med Sci Univ Ilam 14: 1-8.

Tale Masouleh Z, Asadollahi S, Eshaghi M. 2015. Effects of pulsed electric fields as a pre-treatment on yield extraction and some quality properties of sesame oil. Int J Rev Life Sci 5: 1100-1104.

Thiyam-Holländer U, Eskin NM, Matthäus B. 2012. Canola and rapeseed: production, processing, food quality, and nutrition. CRC Press.

Uquiche E, Jeréz M, Ortíz J. 2008. Effect of pretreatment with microwaves on mechanical extraction yield and quality of vegetable oil from Chilean hazelnuts (Gevuina avellana Mol). Innov Food Sci Emerg Technol 9: 495-500.

Valentov O, Novotn Z, Svoboda Z, Schwarz W, Kas J. 2000. Microwave heating and $\gamma$-irradiation treatment of rapeseed (Brassica Napus). J Food Lipids 7: 237-245.

Vuorela S, Meyer AS, Heinonen M. 2004. Impact of isolation method on the antioxidant activity of rapeseed meal phenolics. J Agric Food Chem 52: 8202-8207.

Vuorela S, Kreander K, Karonen M, et al. 2005. Preclinical evaluation of rapeseed, raspberry, and pine bark phenolics for health related effects. J Agric Food Chem 53: 5922-5931.

Wakamatsu D, Morimura S, Sawa T, Kida K, Nakai C, Maeda H. 2005. Isolation, identification, and structure of a potent alkylperoxyl radical scavenger in crude canola oil, canolol. Biosci Biotechnol Biochem 69: 1568-1574.

Wiktor A, Sledz M, Nowacka M, et al. 2015. The impact of pulsed electric field treatment on selected bioactive compound content and color of plant tissue. Innov Food Sci Emerg Technol 30: 69-78.

Zeng X-a, Han Z, Zi Z-h. 2010. Effects of pulsed electric field treatments on quality of peanut oil. Food Control 21: 611-614.

Cite this article as: Mohseni NM, Mirzaei HO, Moghimi M. 2020. Optimization of producing oil and meal from canola seeds using microwave - pulsed electric field pretreatment. $O C L 27: 2$. 